\title{
"Growing" a sustainable community: Health, food, and development at the Aundeck Omni Kaning First Nation ${ }^{1}$
}

\author{
Irene Altiman
}

\begin{abstract}
How can a First Nation community become sustainable and not be primarily reliant on government financing and services? Economic development is one major tool towards this sustainability. The small community of Aundeck Omni Kaning First Nation (AOK), located on Manitoulin Island, has the opportunity to become the top producer and supplier of organic produce in Northern Ontario. This paper explores local CSA, food cooperative, greenhouse, and aquaponics operations as means to reach this goal.
\end{abstract}

Keywords: First Nations, sustainability, agriculture, food, healthy communities

\section{Introduction}

How can a First Nation community become sustainable and not be primarily reliant on government financing and services? Economic development is one major tool towards this sustainability. However, in many communities, longer-range developmental activities must compete with the pressures from all other community needs on a day-to-day basis for resources and attention from leadership and staff to move forward.

A community does not have to be large or ideally located in the conventional sense in order to make significant changes, nor does this change have to be located within the reserve boundaries. The small community of Aundeck Omni Kaning First Nation (AOK), located on Manitoulin Island, has the opportunity to become the top producer and supplier of organic produce in Northern Ontario. Further, it has the potential to become known as the "the healthiest First Nation in Canada".

\section{Community profile}

Aundeck Omni Kaning is a small First Nation community located on the north shore of the largest freshwater island in the world, Manitoulin Island. AOK is just outside the town of Little Current which connects Manitoulin Island to the mainland by a one hundred year old swing bridge. It is one of six First Nations located on Manitoulin Island. The population on-reserve ${ }^{2}$ is 390 members.

Despite being a small community, it manages most of its own services through a band administration office, community health centre, community centre, library, youth centre, tutoring

\footnotetext{
${ }^{1}$ Editor's note: This paper was originally written in 2013. Several important changes have occurred since: the wind turbine project has moved to non-reserve lands and the unused processing plant has been ...

${ }^{2}$ A reserve is a tract of land set aside by the Crown for the use and benefit of a band in Canada. Many First Nations now prefer the term First Nation community, but the term remains in use by the federal government and has legal meaning.
} 
centre, elders centre, and daycare. In addition, there are recreational facilities that include a tennis court; ball field; covered, outdoor rink complete with a Zamboni; a beautiful lakefront park for skateboarding, swimming and boating; and a beach volleyball court. A walking trail runs along the highway from almost one end of the community to the other. There is also a $3 \mathrm{~km}$ hiking trail which makes its way down to the lake front.

AOK rents office space to the Mnaadzawin and Noojmowin Teg Health Centre which offers wholistic and western medicine as well as mental health services to six local First Nations. The Manitoulin Legal Aid clinic, which services all of Manitoulin Island, is located next to the band administration building. The community centre hosts training programs, conferences, and public community events.

Apart from government-assisted revenues and casino-shared revenue; the First Nation derives revenue from a few business operations in addition to two rental properties. Endaa Aang Tourism is a cottage rental business which rents five cottages throughout the summer tourist season. Two cottages are winterized and allow for year round renting. AOK also leases a sixcage rainbow trout farm which employs one full time band member and two community members.

In 2013, AOK is one of eight other First Nations that celebrated the opening of the Manitoulin Hotel and Conference Centre. It is $100 \%$ First Nation owned and employs six AOK community members. Another revenue stream comes from a partnership (in which the six First Nations on Manitoulin Island share a 50\% ownership) in a 24-tower wind power project with Northland Power.

The main employer of the First Nation is the band administration which employs 16 full-time and 20 part-time or seasonal workers in administration and construction. Unemployment remains unacceptable and serves as an incentive for further economic development. The total land base is approximately 664 hectares. Included in the 664 hectares are reserve adjacent farmlands that were purchased by AOK. These lands are being added to the reserve via the Additions to Reserve process with the Federal government and will serve community expansion.

The population of AOK has grown exponentially in the past thirty years, nearly tripling in size. The majority of the population $(58 \%)$ is under the age of 30 which represents both a challenge and a resource. Few seek employment off-reserve. Secondary and post-secondary graduation rates are low but there has been an increase in the number of graduates in the past few years. Successful graduates are almost always adult learners who have returned to school to complete their education.

\section{Community health}

The complex health issues of community members are also of concern. Among First Nations populations, heart disease is 1.5 to 2 times higher (Canadian Heart Health Strategy and Action 
Plan Steering Committee, 2009) and Type 2 diabetes is 3 to 5 times higher, than the general population (Health Canada, 2013). AOK is no exception.

\section{Creating change}

AOK has access to two grocery stores and a distant health food store but, notionally, nutrition quality is low and disease rates are high. By combining healthy eating and creating employment and revenue from agricultural operations, the community of AOK can be a leader in terms of financial and physical health and well-being in addition to being self-sufficient and sustainable for many generations to come. AOK has started its forward movement with a few readily achievable projects and some longer range planning. As Lao Tzu put it: "A journey of a thousand miles begins with a single step".

\section{Food Security and Health}

Getting buy-in from leadership, staff and community members is key to realizing a prosperous and healthy community. Making it easier to buy healthy food is a good start. AOK has already begun a couple of initiatives to promote healthy eating with the Good Food Box program. A food-buying co-op is still in the planning phase.

\section{Good Food Box}

Recently, through the Community Health Centre, AOK has partnered with other communities on Manitoulin Island to bring in the Good Food Box program. The Good Food Box program allows low income families to purchase fruits and vegetables at extremely low prices. Each month, a community is chosen to go pick up the boxes in Sudbury and distribute them to the participating communities. Families have two choices: for $\$ 7$ they can get a small box, or for $\$ 15$ they can get a large box.

To be sure there are a few challenges with this program. Some foods may be unfamiliar so the Health Centre will be hosting workshops to help families in the program to cook different recipes using the fruits and vegetables they receive that month. Another issue is that, for now, the program is only available for ten families to participate. Perhaps in the future the program will be available for anyone who wishes to participate.

Although there are no direct economic benefits to this program, benefits will be seen in improved nutrition and health for immediate participants and hopefully through their experience their extended families.

Food Buying Co-op

Another initiative is a food buying co-op which will enable those who join the cooperative to get access to healthy food choices that are not available locally, especially vegan options. It enables participating families to buy food in bulk and at a lower cost than in the grocery store. A food cooperative requires a minimum of five individuals to participate and it requires two guarantors 
to be responsible for the food charges. A guarantor could be the band administration which could also sponsor a position to oversee the co-op. AOK has an unused fish processing plant which has some refrigeration if needed. It would put back into use as an unused band building and it comes equipped with a loading dock which would make for easier deliveries.

The co-op could negotiate directly with local farmers to purchase fruits and vegetables. Currently, the grocery stores in town do not carry local produce and almost everything is imported. There is no option to buy fresh produce from the Ontario Natural Foods, a supplier of healthy, organic foods. Aundeck Omni Kaning has been working to support local agriculture on a variety of scales. AOK has a few thousand acres of unused farm lands which are available for grazing.

Both the Good Food Box program and the food buying co-op would be a good start to get the community eating healthier. A healthy community works and studies better and has less time and expense lost to health issues.

\section{Mid to long term solutions}

The community of AOK opened a multi-purpose complex that will house a larger community centre, kitchen and office space. This facility is to be located next to the recreational facilities in the heart of the First Nation. A couple of full-time jobs were created as a result of the project and some short-term work was created during the construction phase. Rental income will be generated as the facility is marketed in the area. The majority of the housing in the community runs along Highway 541 which makes its way through the centre of the community. One of the properties purchased has been earmarked for housing. Other properties have been set aside by Chief and Council as proposed industrial lands. A land use plan approved by the majority of the membership will see how this property is to be used.

AOK has the financial ability to fund a farming operation but it would require some strategic planning. Another First Nation in Southern Ontario has been operating a successful agricultural operation for over 30 years. Tahgohning Enterprises, located on the Walpole Island First Nation is a successful farming venture. The corporation was established as a separate entity from the Chief and Council and band administration but is governed by a Board of Directors. The first few years only 50 acres was farmed using rented equipment and employing 2 part-time workers (only 1 band member). During the first years of operations, acreage was continually added and revenues were reinvested back into the enterprise for farm equipment, the development of their own grain elevators and an office.

Another option is greenhouses. Greenhouses have the potential to create employment, fresh produce, and revenue year-round. Local produce is in short supply even in the summer, and during the winter months, most products at the grocery store come from Mexico or the U.S.

Although the cost to start a green house is quite expensive, it can be done in AOK. We could be the number one supplier of local produce. One greenhouse could be for the garden variety 
vegetables found in most grocery stores such as tomatoes, cucumbers and peppers and used to supply the community. Large scale greenhouses could be used to supply Northern Ontario from Sault Ste. Marie to Sudbury and maybe one day the US. Via boat, it is a short distance between the AOK and the US.

Another area that can be explored is aquaponics. Aquaponics combines aquaculture and agriculture to grow fish and vegetables in the same system. The fish waste is converted to nutrients to feed the plants, the plants filter and clean the water and recirculates it back into the system. Aquaponics systems grow vegetables in significantly less time than through normal agricultural practices. The vegetables are larger, organic, and can be grown year round. Fish and vegetables can be grown cyclically to ensure there is continuous supply. The vegetables grown in an aquaponics system are mainly leafy greens and herbs and vine vegetables. The fish raised could be rainbow trout or tilapia but in this case it makes sense to grow rainbow trout. Aside from small scale back yard type operations, there are no commercial scale aquaponics operations in Northern Ontario. Green Relief in Flamborough, Fresh City Farms in Downsview, and Aqua Greens in Mississauga are all successful aquaponics operations in Southern Ontario.

AOK has the knowledge and capacity in aquaculture as they have operated and subsequently leased a rainbow trout net pen operation for the past 20 years. The aquaculture operation employs several community members who are all knowledgeable in rearing fish. While initially capital intensive, the benefits far outweigh the initial investment. An aquaponics system would employ community members year round. It would supply the community members with yearround fresh vegetables and fish. Excess fish and vegetables can be sold to local markets. Over time, a restaurant or store could be added resulting in more jobs and revenue streams for the community. Done on a commercial scale, it could be the main supplier of fresh, organic vegetables and fish in Northern Ontario.

\section{Conclusion}

Growing a sustainable community for the future of AOK can be a reality with the right planning and implementation. Leadership is required but the ideas presented in this paper offer opportunities for a better future.

Rather than remain dependent on government transfers, First Nations are increasingly participating in development opportunities that create long term employment and revenue. AOK has partnered with other First Nations in the Manitoulin Hotel and wind farm project to create these kinds of impacts.

Poor health and poor access to fresh foods are recognized as an issue. However, the First Nation has acquired adjacent farm lands and new possibilities can be explored. Local CSA, food cooperative, greenhouse, and aquaponics operations are being considered and the successes in First Nations such as Walpole Island serve as good role models. 


\section{Author biography}

Irene Altiman is a member of the Aundeck Omni Kaning First Nation, a newly elected Band Councillor, and the Regional Initiatives Coordinator for the Waubetek Business Development Corporation.

Food and health are important topics to Irene. She suffered a heart attack at age 38, which caused her to rethink her former unhealthy lifestyle. Thanks to a vegan diet, regular exercise, and smoke-free living, she is now 50 pounds lighter and less dependent on medication.

\section{References}

Canadian Heart Health Strategy and Action Plan Steering Committee (2009). Canadian Heart Health Strategy and Action Plan: Building a Heart Healthy Canada. Ottawa, Canada.

Health Canada (2013). First Nations \& Inuit Health: Diabetes. Retrieved from http://www.hcsc.gc.ca/fniah-spnia/diseases-maladies/diabete/index-eng.php 